\title{
Mineral Resources of the El Paso Mountains Wilderness Study Area, Kern County, California
}

\section{U.S. GEOLOGICAL SURVEY BULLETIN 1708-C}

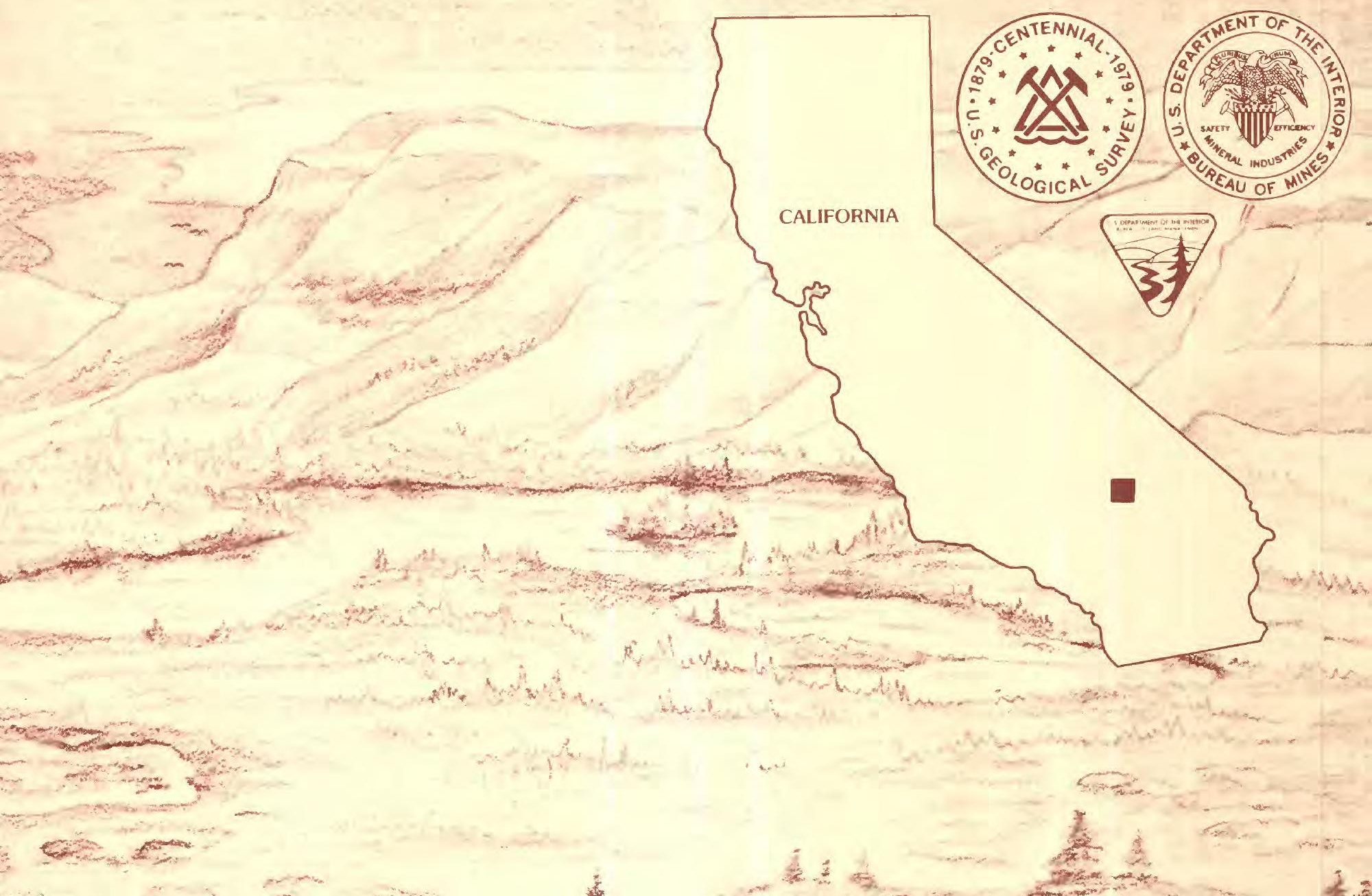




\section{Mineral Resources of the El Paso Mountains Wilderness Study Area, Kern County, California}

BY MICHAEL F. DIGGLES, BRETT F. COX, and ROBERT E. TUCKER

U.S. Geological Survey

RICHARD S. GAPS

U.S. Bureau of Mines 


\title{
DEPARTMENT OF THE INTERIOR
}

DONALD PAUL HODEL, Secretary

\author{
U.S. GEOLOGICAL SURVEY
}

Dallas L. Peck, Director

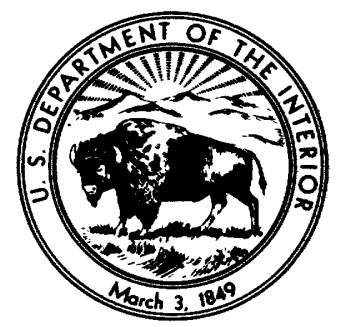

UNITED STATES GOVERNMENT PRINTING OFFICE $\quad: 1985$

For sale by the

Distribution Branch, Text Products Section

U.S. Geological Survey

604 South Pickett St.

Alexandria, VA 22304

Library of Congress Cataloging-in-Publication Data

Main entry under title:

Mineral resources of the EL Paso Mountains Wilderness

study area, Kern County, California.

(U.S. Geological Survey Bullet in 1708-C)

Bibliography: p. C $9-\mathrm{C} 10$

Supt. of Docs. no.: I 19.3:1708-C

1. Mines and mineral resources--California--EL Paso

Mountains Wilderness. 2. El Paso Mountains Wilderness

(Calif.). I. Diggles, Michael F. II. Series: United

States. Geological Survey. Bullet in 1708-C.

QE75.B9 no. 1708-C 557.3s 85-600498

[TN24.C2] [553'.09794'88] 


\section{STUDIES RELATED TO WILDERNESS}

\section{Bureau of Land Management Wilderness Study Areas}

The Federal Land Policy and Management Act (Public Law 94-579, October 21, 1976) requires the U.S. Geological Survey and the U.S. Bureau of Mines to conduct mineral surveys of certain areas to determine the mineral values, if any, that may be present. Results must be made available to the public and be submitted to the President and the Congress. This report presents the results of a mineral survey of the El Paso Mountains Wilderness Study Area (CDCA-164), California Desert Conservation Area, Kern County, California. 


$$
\text { . }
$$




\section{CONTENTS}

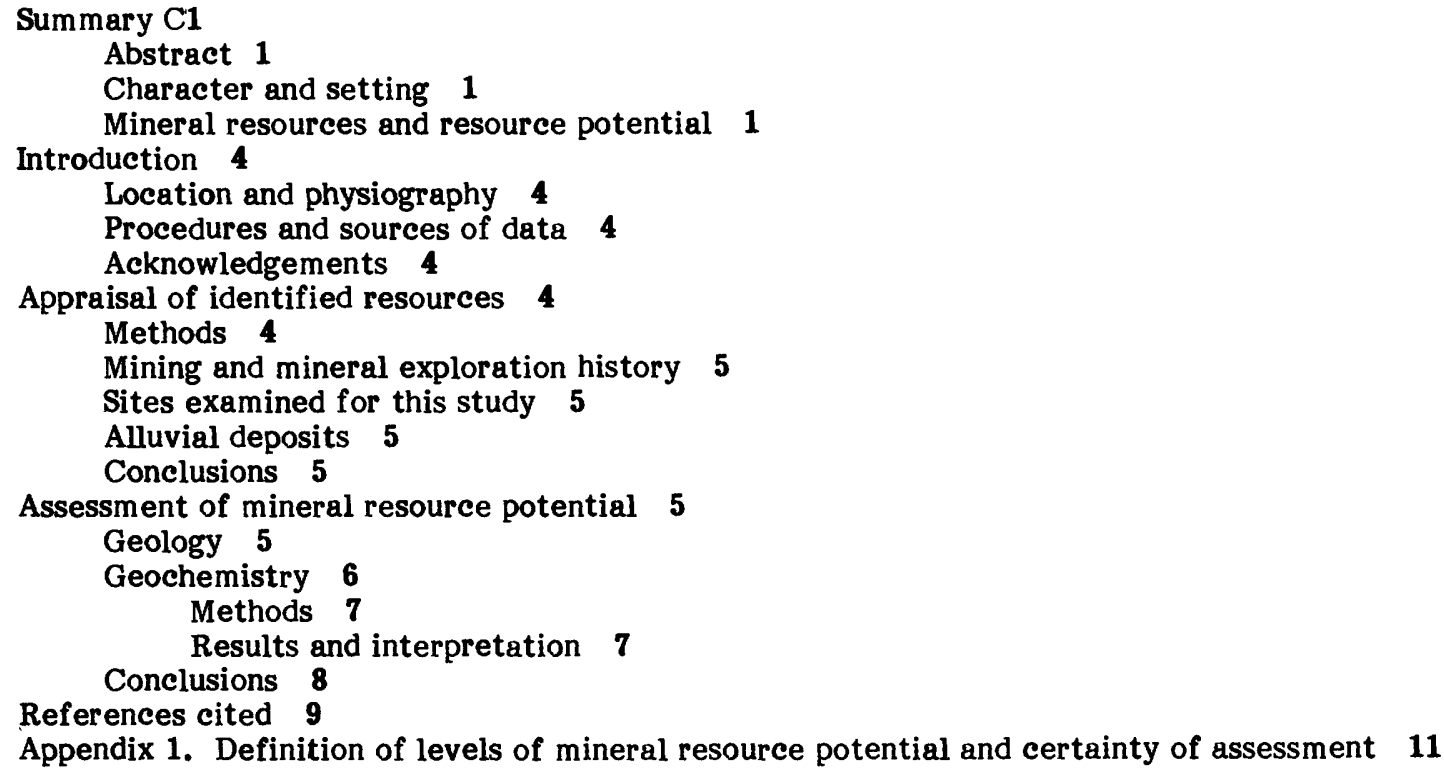

\section{PLATE}

In Pocket

1. Mineral resource potential map of the El Paso Mountains Wilderness Study Area, Kern County, California

\section{FIGURES}

1. Index map showing location of the El Paso Mountains Wilderness Study Area, Kern County, California C2

2. Mineral resource potential map of the El Paso Mountains Wilderness Study Area, Kern County, California 3

3. Major elements of mineral resource potential/certainty classification 11

\section{TABLE}

1. Mines, prospects, and claims in and adjacent to the El Paso Mountains Wilderness Study Area C12 


\title{
Mineral Resources of the El Paso Mountains Wilderness Study Area, Kern County, California
}

\author{
By By Michael F. Diggles, Brett F. Cox, and \\ Robert E. Tucker \\ U.S. Geological Survey
}

Richard S. Gaps

U.S. Bureau of Mines

\section{SUMMARY}

\begin{abstract}
The El Paso Mountains Wilderness Study Area (CDCA-164) encompasses 13,252 acres of mountainous desert land located approximately $10 \mathrm{mi}$ southwest of Ridgecrest, Calif. A mineral resource survey of the area included geologic mapping, a geochemical survey of stream sediments, and a study of mines, prospects, and mineralized areas. There are no known currently or formerly productive mineral deposits in the study area. Copper and placer gold prospects that are located a short distance to the south occur in geologic environments that are not found within the study area. The study area has low mineral resource potential for gold in silicified rocks. Common industrial materials, including pumice, sand, and gravel, are also present but they can not currently be mined profitably, and alternative sources are available closer to populated areas.
\end{abstract}

\section{Character and Setting}

The El Paso Mountains Wilderness Study Area, located on the north flank of the El Paso Mountains approximately $10 \mathrm{mi}$ southwest of Ridgecrest, Calif. (fig. 1), encompasses 13,252 acres of mountainous desert terrain, including Black Mountain and most of the Black Hills. Elevations range from approximately $2,800 \mathrm{ft}$ at the north edge of the study area to $5,244 \mathrm{ft}$ at Black Mountain. The Black Hills consist of gently sloping tableland dissected by narrow canyons that drain mostly toward the north and west. Areas of lower elevation include deeply gullied badlands east of the Black Hills and small alluvial fans along the northwest foot of the Black Hills.

The recently active Garlock fault and subsidiary faults bound the south side of the El Paso Mountains (fig. 2) and are responsible for their east-northeast trend. A ridge of pre-Tertiary plutonic and metamorphic rocks, exposed immediately southeast of the study area, forms the core of the El Paso Mountains. The pre-Tertiary rocks are unconformably overlain on the north flank of the range by Tertiary sedimentary and volcanic rocks that are exposed throughout the study area. Directly north and west of the study area, the Tertiary strata are covered by large alluvial fans of Quaternary age that extend eastward from the southern Sierra Nevada.

The principal mineral products of the El Paso Mountains region have been placer gold, pumice and pumicite, and bentonitic clay; although prospecting and small-scale mining for coal, lode gold, copper, and molybdenum also occurred. Nearly all mineral production has come from properties south of the study area. Mining activity began in 1893 with the discovery of placer gold near Goler Gulch. During the 1890 's and again during the 1930 's, dry-wash placer operations yielded modest amounts of gold from Quaternary terrace gravel located along Goler and Bonanza Gulches. Prospectors never located the bedrock source of the placer gold, although small quantities of gold, lead, manganese, and silver were recovered as by-products of small-scale copper mining in the metamorphic and plutonic rocks. An undetermined amount of lignitic coal was mined for local consumption during the 1890's; several tens of thousands of tons of bentonitic clay were mined between 1920 and 1940; and approximately 150,000 tons of pumice and pumicite were produced between 1920 and 1960. Most recently, basalt rubble and Quaternary sand and gravel have been produced from quarries near the north end of the study area. The sand and gravel currently are being mixed with asphalt at a portable plant $1.5 \mathrm{mi}$ northeast of the study area to produce road-surfacing materials. The basalt rubble presumably has been used as riprap.

\section{Mineral Resources and Resource Potential}

There are no identified metallic mineral 


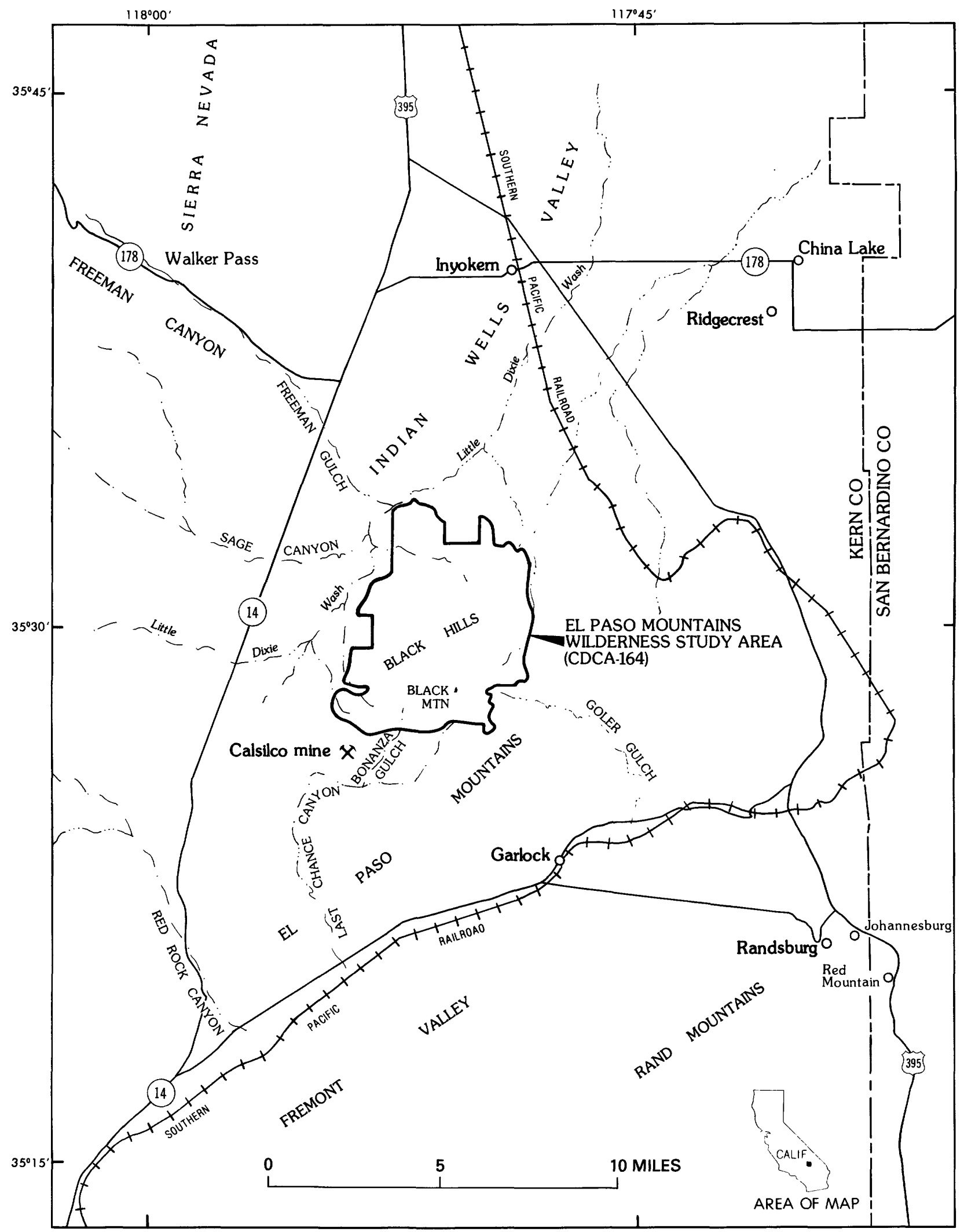

Figure 1.--Index map showing location of the El Paso Mountains Wilderness Study Area, Kern County, California 


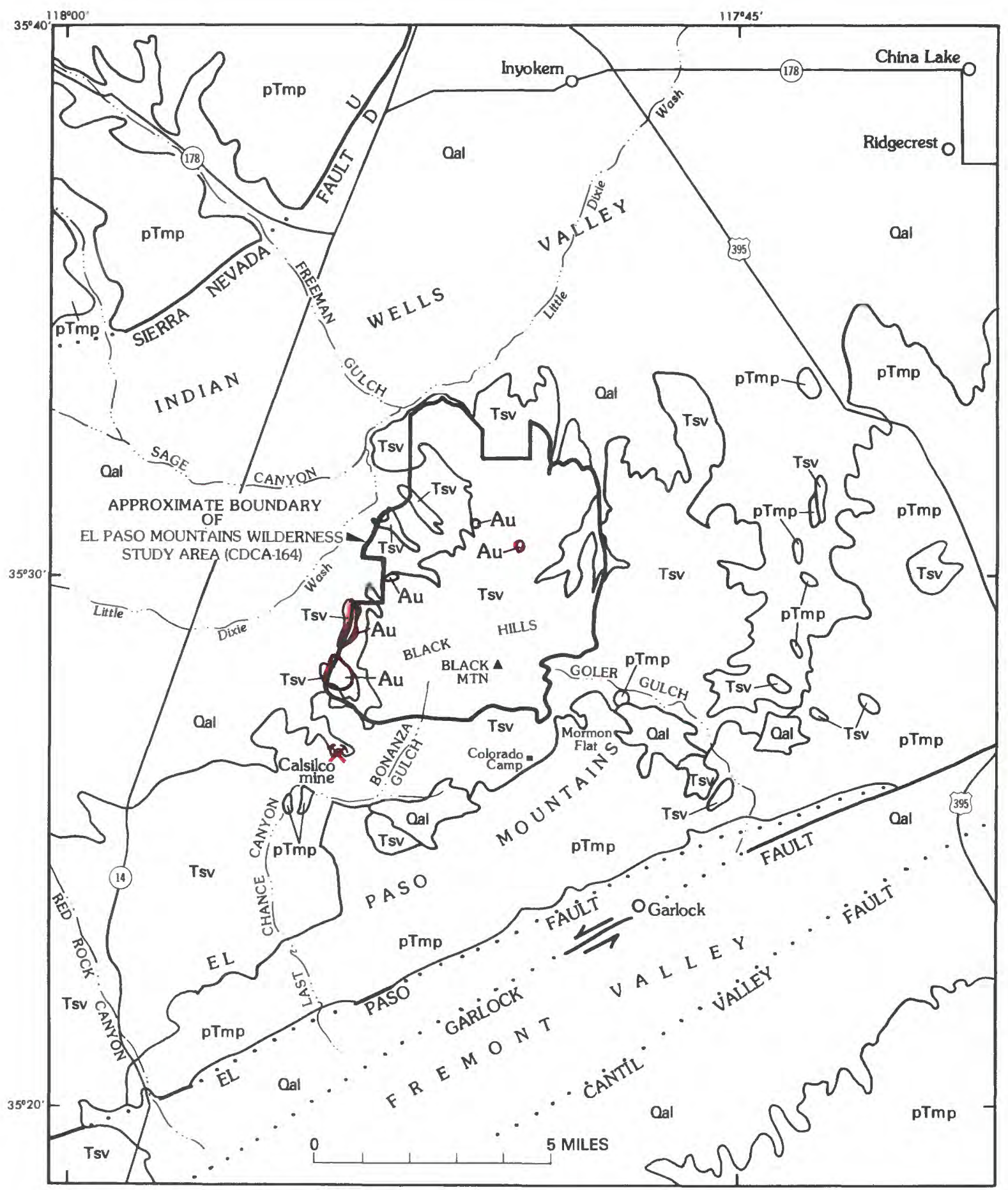

EXPLANATION

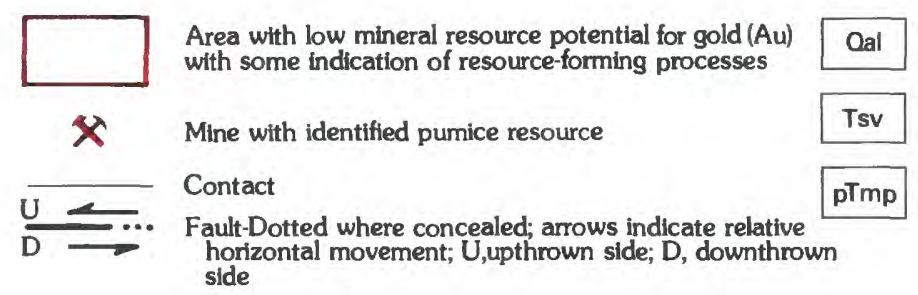

Alluvium (Quatemary)

Sedimentàry and volcanic rocks (Tertiary)

Metamorphic and plutonic rocks (pre-Tertiary)

Figure 2.--Mineral resource potential map of the E1 Paso Mountains Wilderness Study Area, Kern County, California 
resources in the El Paso Mountains Wilderness Study Area. Despite numerous occurrences of metallic minerals and minor production of copper ore from preTertiary rocks to the south, similar mineral occurrences have not been found in the Tertiary rocks of the study area. Auriferous Quaternary terrace gravel just southwest of the study area does not extend into the area. Pumice, basalt rubble, and alluvial gravel are present but more viable sources of these materials exist elsewhere.

Geologic and geochemical investigations of the study area suggest there is low potential for epithermal gold in five areas where silicified rock is present (fig. 2).

\section{INTRODUCTION}

\section{Location and Physiography}

The El Paso Mountains Wilderness Study Area (CDCA-164) is located on the north flank of the E1 Paso Mountains between California State Highway 14 and U.S. Highway 395 approximately $10 \mathrm{mi}$ southwest of Ridgecrest, Calif. (fig. 1). A subsidiary line of the Southern Pacific Railroad passes within a few miles to the south and east. Low-lying areas adjacent to the study area are accessible by infrequently maintained dirt roads and jeep trails, but no roads or trails extend into the interior. The study area encompusses 13,252 acres of sparsely vegetated mountainous terrain, including Black Mountain and most of the Black Hills. Elevations range from approximately $2,800 \mathrm{ft}$ in Little Dixie Wash at the north edge of the study area to $5,244 \mathrm{ft}$ at Black Mountain. The Black Hills consist of gently sloping tableland dissected by narrow canyons that drain toward the north and west. Areas of lower elevation include deeply gullied badlands east of the Black Hills and small alluvial fans along the northwest foot of the Black Hills.

\section{Procedures and Sources of Data}

Both new field and laboratory studies conducted during 1982 and 1983, and previous reports and public documents provided data for the conclusions of this report. The U.S. Bureau of Mines reviewed literature, mining claim records, and production records, and inspected mines, prospects, claims, and mineralized areas in and near the study area. They collected rock samples at prospects and mineralized areas and heavymineral concentrate samples from alluvium in selected drainages to be analyzed for elements of possible economic significance. These data were used to determine past and present mining and mineral exploration activities and to characterize mineral resources within and immediately adjacent to the study area (Gaps, 1984).

The U.S. Geological Survey compiled a detailed $1: 24,000$-scale geologic map of the study area, largely on the basis of field work conducted during the present investigation (B.F. Cox and M.F. Diggles, unpub. data 1984). A generalized version of this geologic map is shown on plate 1. Stream sediment from active channels was chemically analyzed so that chemical variations reflecting concentrations of ore minerals or activity of ore-forming processes could be identified (Detra and others, 1984). The geologic field observations and geochemical data were evaluated together with the information obtained by the U.S. Bureau of Mines to assess identified mineral resources and the potential for undiscovered mineral resources in the study area.

Several geologic and mineral-resource reports dealing with the El Paso Mountains region were consulted for this study. The study area is encompassed by geologic maps of the Saltdale and Inyokern 15-minute quadrangles (Dibblee, 1952, 1954) that have also been incorporated within small-scale maps of the Trona $1^{\circ}$ by $2^{\mathrm{O}}$ quadrangle (Jennings and others, 1962), Kern County (Troxel and Morton, 1962), and western Mojave Desert (Dibblee, 1967). Cox (1982) mapped along the south and east sides of the study area as part of a stratigraphic study of the Goler Formation. Dibblee and Gay (1952) and Troxel and Morton (1962) described the mineral resources of the El Paso Mountains region. The uranium potential of the Trona $1^{\circ}$ by $2^{\circ}$ quadrungle, which includes the El Paso Mountains, was assessed by Bushnell and Morton (1982). Mining claim information was acquired from records of Kern County and the U.S. Bureau of Land Management, and production records were obtained from U.S. Bureau of Mines and state documents.

\section{Acknowledgements}

J. Douglas Causey of the U.S. Bureau of Mines and Eduardo Rodriguez, Nancy Parduhn, David Dellinger, and Jamie Conrad of the U.S. Geological Survey assisted in the field work. Margaret Phillips and Mark Lawrence of the Bureau of Land Management Ridgecrest Resource Areu Office provided logistical support and information on current mineral resource activities.

\section{APPRAISAL OF IDENTIFIED RESOURCES}

By Richard S. Gaps, U.S. Bureau of Mines

\section{Methods}

Work by the U.S. Bureau of Mines spanned the years 1983 and 1984. Pre-field studies included library research and perusal of claim and production records; field work included examination of eight prospects and claims, three within the study area and five adjacent to it (pl. 1). In addition, ground and air reconnaissance was done in ureas of silicified rock. Rocks and activestream alluvium were sampled and analyzed to determine abundances of selected elements ( $\mathrm{Ag}, \mathrm{Al}$, As, $\mathrm{Au}, \mathrm{B}, \mathrm{Ba}, \mathrm{Be}, \mathrm{Bi}, \mathrm{Ca}, \mathrm{Cd}, \mathrm{Co}, \mathrm{Cr}, \mathrm{Cu}, \mathrm{Fe}, \mathrm{Ga}, \mathrm{K}$, $\mathrm{La}, \mathrm{Li}, \mathrm{Mg}, \mathrm{Mn}, \mathrm{Mo}, \mathrm{Na}, \mathrm{Nb}, \mathrm{Ni}, \mathrm{P}, \mathrm{Pb}, \mathrm{Pd}, \mathrm{Pt}, \mathrm{Sb}, \mathrm{Sc}$, $\mathrm{Si}, \mathrm{Sn}, \mathrm{Sr}, \mathrm{Ta}, \mathrm{Te}, \mathrm{Ti}, \mathrm{V}, \mathrm{Y}, \mathrm{Zn}$, and $\mathrm{Zr}$ ) of potential economic interest. The rock samples were collected from prospects and from other areas where mineralization was suspected to have occurred. Sandy alluvium was reduced to a heavy-mineral concentrate in the field by panning.

Elements suspected to be present were chemically 
chemically determined by atomic-absorption, colorimetric, radiometric, X-ray fluorescence, or other quantitative methods. At least one sample from each locality was analyzed for 40 elements by semiquantitative emission spectroscopy to detect any unsuspected elements of possible significance that might also be present; those elements indicated to be present in anomalous concentrations were then redetermined by one of the quantitative methods.

\section{Mining and Mineral Exploration History}

No active mines are located within or adjacent to the El Paso Mountains Wilderness Study Area. The nearest active mining operation is in Goler Gulch (figs. 1 and 2), approximately $4 \mathrm{mi}$ to the southeast. Approximately 100 claims are currently being held within and adjacent to the study area, but no exploration or development work is being done on them.

Mining activity began in the El Paso Mountains district with the discovery of placer gold in Goler Gulch in 1893. Modest quantities of placer gold were recovered from Quaternary bench gravel and from modern gravel filling the deeper canyons, particularly Goler Gulch and Bonanza Gulch. The district has been attributed with over $\$ 50,000$ in gold production during 1893 (Vredenburgh and others, 1981), however production figures are incomplete. Mining in the district declined by 1900 , but revived for a few years in the 1930's. Additionally, some prospecting has been done in the pre-Tertiary rocks for lode gold, copper and molybdenum.

In 1923 the Cudahy Packing Company began mining pumice, pumicite, and bentonitic clay from a layer of white pumice-lapilli tuff $2.5 \mathrm{mi}$ southwest of the study area (Chesterman, 1956; Troxel and Morton, 1962). By 1947 about 120,000 tons of pumicite had been mined (Troxel and Morton, 1962). Starting in 1939 pumice was produced at the Calsilco mine (pl. 1). Total production, as of 1958, was greater than 25,000 tons of raw material (Troxel and Morton, 1962). The mine has been inactive for several years. The tuff forms a layer a few inches to $50 \mathrm{ft}$ thick at the base of the tuffaceous rocks unit of the Miocene Ricardo Formation of Dibblee (1952). Previous work showed that the main outcrop of this layer extends from a point near Red Rock Canyon (figs. 1 and 2) northeastward for about $7 \mathrm{mi}$ to a termination at the southwest margin of the study area (Troxel and Morton, 1962, fig. 8). Zones of altered tuff at the southwest end of the layer contain clay, whereas pumice was mined mainly from the Calsilco mine at the northeast end of the layer. Mapping for the present study (B.F. Cox and M.F. Diggles, unpub. data, 1984) revealed that the same white pumice-lapilli tuff layer crops out discontinuously within the study area on the northeast face of Black Mountain and on several steep slopes within $2 \mathrm{mi}$ of the southwest corner of the study area. Numerous faults and landslides disrupt these relatively small and inaccessible exposures. These pumice-tuff outcrops are generally unaltered and lack zones of bentonitic clay.

An undetermined amount of lignitic coal was produced in the 1890 's from a carbonaceous lens in the
Goler Formation (Paleocene and Eocene) near Colorado Camp about $1 \mathrm{mi}$ south of the study area (Dibblee, 1952, p. 23, 25; Dibblee and Gay, 1952; Troxel and Morton, 1962, p. 83). Coal seams have not been observed in other areas, although the Goler Formation contains moderate quantities of carbonaceous siltstone northeast of Black Mountain and at several locations outside the study area.

Recent mineral related activity in the area has been chiefly limited to minor placer gold production and assessment work. However, in 1982 Shell Oil Company located a large block of lode mining claims along the southeast border of the study area.

\section{Sites Examined for this Study}

Eight prospects and claims, three inside the El Paso Mountains Wilderness Study Area and five outside, were examined during this study (pl. 1). Information concerning workings, production, samples, and resource data for these prospects and the Calsilco mine are are given in table 1 .

\section{Alluvial Deposits}

Nine alluvial samples were collected in gullies that drain from the study area (pl. 1). The two samples taken from separate drainages near the Dennis claims (map No. 8) at the southeast corner of the study area contained anomalous concentrations of arsenic, antimony, and tungsten. These elements are commonly associated with gold deposition in active hot springs (Weissberg, 1969), with hot-spring-type epithermal gold deposits (Bonham and Giles, 1983), and as halos around gold deposits (Atabek'yants, 1973).

\section{Conclusions}

No mineral resources were identified, and there is no record of past mineral production from the $\mathrm{El}$ Paso Mountains Wilderness Study Area.

Pumice deposits in the study area generally occur on steep slopes stratigraphically below the Black Mountain Basalt (Miocene). The steep topography and thick overburden preclude open-pit mining of these deposits, and underground mining would not be economic at the 1984 price of about $\$ 9.00$ per ton, freight on board (F.O.B.), at the mine (Meisinger, 1984).

\section{ASSESSMENT OF MINERAL RESOURCE POTENTIAL}

By Michael F. Diggles, Brett F. Cox, and Robert E. Tucker, U.S. Geological Survey

\section{Geology}

The El Paso Mountains lie in the southwest corner of the Basin and Range Province, between the Garlock and Sierra Nevada faults (fig. 2). The El Paso fault, a high-angle normal fault that merges eastward with the Garlock fault, uplifted the range relative to 
Fremont Valley. The Garlock fault is a major regional strike-slip. fault with a cumulative Cenozoic leftlateral displacement of 30 to $40 \mathrm{mi}$ (Smith, 1962; Smith and Ketner, 1970). Late Cenozoic movement on the Sierra Nevada fault uplifted the southern Sierra Nevada relative to the El Paso Mountains.

Pre-Tertiary plutonic and metamorphic units, which form the core of the El Paso Mountains, lie immediately southeast of the study area. One of these units, the Garlock assemblage (the now-abandoned Garlock Formation and now-abandoned Mesquite Schist of Dibblee, 1952), extends into the southeast corner of plate 1. The Garlock assemblage (Carr and others, 1984) consists of Ordovician to Permian eugeoclinal sedimentary and volcanic rocks that have been intensely folded, faulted, and metamorphosed to the greenschist facies. Outside the map area Permian and Mesozoic plutons intrude the Garlock assemblage.

Tertiary sedimentary and volcanic rocks and Quaternary alluvial deposits that unconformably overlie the pre-Tertiary units to the south cover the entire study area. Three Tertiary units are present: the Goler Formation of Paleocene and Eocene age; the Ricardo Formation of Dibblee (1952) of Miocene age; and the Black Mountain Basalt which is here geographically restricted to the original usage of Baker (1912) and is considered early and middle Miocene in age based on potassium-argon determinations ranging from $15.1 \pm 0.5$ (J.L. Morton, unpub. data, 1979) near its top to $17.9 \pm 1.6 \mathrm{m.y}$. (M.F. Diggles, unpub. data, 1982) near its base. Although the Goler and Ricardo Formations contain numerous mappable lithologic subunits (B.F. Cox and M.F. Diggles, unpub. data, 1984), for this report the Goler Formation is mapped as a single lithologic unit and the Ricardo Formation is divided into four units (pl. 1).

The Goler Formation consists of north-dipping beds of fluvial conglomerate, pebbly sandstone, and siltstone that are exposed along the east and south sides of the study area. In addition, recent studies (Cox and Edwards, 1984; B.F. Cox, unpub. data, 1985) indicate that siltstone deposits exposed near the north margin of the study area accumulated in a marine setting.

The Ricardo Formation (Dibblee, 1952), which crops out in the western part of the study area, consists of horizontal to gently northwest-dipping nonmarine sedimentary and voleanic rocks that unconformably overlie the Goler Formation. In ascending stratigraphic order, the following four generalized units of the Ricardo Formation are shown on plate 1: (1) the conglomerate unit of Bonanza Gulch, consisting of fluvial conglomerate and pebbly sandstone; (2) a unit of tuffaceous rocks, which also contains a layer of andesite breccia that is shown only in the southwest part of the map where it attains its greatest thickness; (3) a thin unit of andesite flows; and (4) a unit of heterogeneous sedimentary rocks of fluvial and lacustrine origin, consisting of conglomerate, sandstone, cherty mudstone, and cherty limestone.

Olivine-augite basalt flows of the Black Mountain Basalt cap the summit of Black Mountain and crop out throughout the Black Hills. The basalt overlies the tuffaceous rocks unit of the Ricardo Formation and in turn locally is overlain by the heterogeneous sedimentary rocks unit at the west edge of the Black Hills. Thus it occupies approximately the same vertical stratigraphic position as the much thinner andesite flows unit of the Ricardo Formation, which is exposed farther west. Basalt dikes near the northeast and southwest ends of the Black Hills represent fissures from which flows of the Black Mountain Basalt issued.

Quaternary alluvium composed of sand and gravel forms extensive alluvial fans deposited by Sierra Nevadan streams northwest of Little Dixie Wash, as well as smaller locally derived alluvium along canyon bottoms and in alluvial fans, stream terraces, and pediment veneers around the margins of the study area. Landslides containing debris derived from the Black Mountain Basalt and Ricardo Formation are abundant on hillsides throughout the study area. Rockslump landslides, indicated by arrows on plate 1 , are particularly abundant on steep slopes in the southern half of the study area. Large blocks of intact strata and sheets of fragmented strata that slid parallel to bedding planes are mainly restricted to gentle slopes near the north end of the study area; these landslide blocks and sheets are surrounded by hachured lines on the map.

The Tertiary strata exposed in the study area, unlike the pre-Tertiary rocks that form the core of the El Paso Mountains, are unmetamorphosed and essentially undeformed. However, an angular unconformity between the tilted Goler and less-tilted Ricardo Formations indicate that they have been subjected to two episodes of gentle tilting. The rocks are locally intruded by basalt dikes, and are cut by numerous minor faults. In addition, the Ricardo Formation locally contains silicified rocks of possible hydrothermal origin in the north and southwest parts of the study area, and the Goler Formation locally is cut by prominent hydrothermal veins east and southeast of the study area.

The geology of the El Paso Mountains Wilderness Study Area is generally unfavorable for the occurrence of undiscovered mineral resources. Known lode occurrences of metallic minerals in the region are restricted to the metamorphic and plutonic rocks that crop out along the core of the range southeast of the study area, and the available evidence (Dibblee and Gay, 1952; Troxel and Morton, 1962), suggests that these mineral concentrations formed mainly during the Mesozoic. Within the study area, the pre-Tertiary rocks are concealed beneath a veil of Tertiary rocks consisting of the Paleocene and Eocene Goler Formation, the Miocene Ricardo Formation and the Miocene Black Mountain Basalt. Although the depth to pre-Tertiary rocks beneath the study area is unknown, seismic refraction work near the north end of the study area (near the center of sec. 29 , T. 27 S., R. 39 E.) indicates a depth between 2,250 (Zbur, 1963, fig. 11) and $4,000 \mathrm{ft}$ (Cox, 1982, fig. 11).

The Tertiary rocks of the El Paso Mountains locally contain hydrothermal features that were examined for possible mineral resource significance. The most conspicuous features are 2- to 5-ft-thick, steeply dipping veins that cut the Goler Formation east and southeast of the study area (pl. 1). The trend and mineralogy of these veins changes from north to south. Veins east of the central part of the study area 
trend north or north-northeast and consist of chalcedony and opal; veins farther south are more variable in orientation, trending mostly east-northeast, and consist of ealcite with common drusy voids. A few veins also eut the Goler Formation in the eastern third of the study area. These veins show the same variations as those to the east but are relatively sparse and generally less than 6 in. wide; none of these minor veins are shown on plate 1 . Field evidence of mineralizing activity associated with any of the veins is lacking; moreover, samples from two calcareous veins and two siliceous veins were analyzed by emission spectrography and found to lack anomalous concentrations of ore-forming elements. Wallrock alteration is also generally absent except for local argillic alteration seen along some of the larger siliceous veins east of the study area.

Another possible hydrothermal feature which erops out at several places is silicified rocks in the Ricardo Formation (pl. 1, stippled pattern). Two small outcrops of silicified rocks (tuff and limestone) are present in the north-central part of the study area. Also, cherty lacustrine limestone and argillaceous mudstone are exposed over a large area near the southwest margin of the study area. The chert consists of abundant irregular masses, tabular zones, and fracture fillings of opal and chalcedony. The origin of the chert is uncertain (Dibblee, 1952, p. 26) and may represent either hydrothermal sinter deposited penecontemporaneously with the sedimentary host rocks or may represent silica that was derived later from the devitrification of volcanic ash contained within the sediments. A diagenetic origin resulting from devitrification seems more likely because the veining and alteration that would be among the expected results of hydrothermal activity are not observed in the strata that directly underlie the cherty sediments. Furthermore, the silicified rocks in or near the study area do not exhibit ironoxide stains or other visible signs of hydrothermal activity. Nevertheless, samples of siliceous material analyzed by the U.S. Bureau of Mines contains minor amounts of gold, silver, and tungsten (table 1, nos. 3 and 6). These elements might have been introduced by hydrothermal processes, and therefore a hydrothermal origin for the silicified rocks cannot be ruled out.

The veins and possibly the zones of silicified rocks in and near the study area were products of hydrothermal systems that probably accompanied regional Miocene volcanism. All Tertiary intrusive bodies exposed within or near the study area consist of Miocene basalt except for two small dikes composed of andesite and rhyolite (B.F. Cox and M.F. Diggles, unpub. data, 1984) that are located west and southwest of the study area. This is noteworthy because intrusions of rhyolitic and andesitic magma, rather than basalt, typically are associated with epithermal mineral deposits. Since there are no active hot springs, fumaroles, nor Quaternary voleanic rocks in this region, the presence of active geothermal systems is unlikely.

\section{Geochemistry}

The U.S. Geological Survey conducted a reconnaissance stream-sediment geochemical survey of the El Paso Mountains Wilderness Study Area in the spring of $\mathbf{1 9 8 2}$ in order to identify patterns of streamsediment chemistry that might reflect mineralized rock. Methods and results of the survey have been deseribed by Detra and others (1984) and are summarized and interpreted below.

\section{Methods}

Sandy alluvium was collected at 33 sites along dry stream beds in and near the wilderness study area (pl. 1). Two samples were collected at each site. One was screened to produce a minus-80-mesh fraction; the other was reduced to a nonmagnetic heavy-mineral concentrate by hand panning, bromoform immersion, and electromagnetic separation. All samples were analyzed for 31 elements ( $\mathrm{Ag}, \mathrm{As}, \mathrm{Au}, \mathrm{B}, \mathrm{Ba}, \mathrm{Be}, \mathrm{Bi}$, $\mathrm{Ca}, \mathrm{Cd}, \mathrm{Co}, \mathrm{Cr}, \mathrm{Cu}, \mathrm{Fe}$, La, Mg, $\mathrm{Mn}, \mathrm{Mo}, \mathrm{Nb}, \mathrm{Ni}, \mathrm{Pb}$, $\mathrm{Sb}, \mathrm{Sc}, \mathrm{Sn}, \mathrm{Sr}, \mathrm{Th}, \mathrm{Ti}, \mathrm{V}, \mathrm{W}, \mathrm{Y}, \mathrm{Zn}$, and $\mathrm{Zr}$ ) using a semiquantitative direct-current are emissionspeetrographic method (Grimes and Marranzino, 1968).

\section{Results and interpretation}

The analytical data for the minus-80-mesh stream-sediment samples provide no evidence of mineralized rocks in the El Paso Mountains Wilderness Study Area. Element abundances fall within limited ranges that are reasonable for detritus of nonmineralized sedimentary and volcanic rocks. Furthermore, the maximum values for each element show little tendency to cluster geographically.

The data for nonmagnetic heavy-mineral concentrate samples include well-defined geochemical anomalies that are scattered in the eastern half of the study area (see pl. 1). The only pronounced anomalies are for barium ( 6 samples with more than 10,000 parts per million (ppm)). Minor anomalies exist for boron (12 samples with 100 to $300 \mathrm{ppm}$ ), lead (2 samples with 100 ppm), silver ( 1 sample with $1 \mathrm{ppm}$ ), and tungsten (1 sample containing an amount below the 100-ppm lower analytic determination limit). Anomalous strontium values (12 samples with 1,000 to $2,000 \mathrm{ppm}$ ) are mostly concentrated in the east half of the study area but are also present near the southwest corner of the area. All of the anomalies occur within drainage basins that contain extensive outcrops of the Goler Formation and (or) the conglomerate unit of Bonanza Gulch (of the Ricardo Formation). This is also true for the antimony, arsenic, and tungsten geochemical anomalies identified by the U.S. Bureau of Mines (see preceding section and pl. 1). Lack of anomalies in the western part of the study area may reflect the lack of exposure of the Goler Formation and conglomerate unit of Bonanza Gulch due to their burial beneath voleanic rocks. The Goler Formation and the conglomerate unit of Bonanza Gulch, which contain a moderate abundance of detrital heavy-mineral grains, presumably supplied a large proportion of the heavymineral grains that are found in the drainages that yielded geochemical anomalies. The anomalies probably are not derived from hydrothermat veins that cut the Goler Formation near the east edge of the 
study area. Numerous veins examined in the field all lacked visible evidence of mineralization; moreover, chip samples from two calcareous veins and two siliceous veins were analyzed by emission spectrography and found to lack anomalous concentrations of ore-forming elements.

Therefore, the stream-sediment anomalies probably record the chemical signature of detritalmineral suites in the Tertiary rocks, rather than epithermal mineralization within the study area. For example, the anomalies for barium, boron, and tungsten most likely represent detrital grains of barite, tourmaline, and scheelite; and the anomalies for antimony, arsenic, lead, silver, and strontium may represent chemical impurities in these and other detrital heavy minerals. This suggests the plutonic bedrock source areas of both the Goler Formation and the conglomerate unit of Bonanza Gulch may have been mineralized. Provenance studies indicate that these source areas are well outside the study area (Cox, 1982; B.F. Cox and M.F. Diggles, unpub. data, 1984), and the concentration of heavy minerals in the sedimentary rocks themselves is far too low to constitute a placer mineral resource. Therefore, the geochemical anomalies have no apparent mineral resource significance for the El Paso Mountains Wilderness Study Area.

Previous regional uranium surveys (Bushnell and Morton, 1982) and aerial gamma-ray emission studies (Geodata International, 1978) found no indication of anomalous uranium in the vicinity.

\section{Conclusions}

The investigations by the U.S. Geological Survey and the U.S. Bureau of Mines suggest that there is low mineral resource potential for hot-springs-type epithermal gold in five areas where silicified rocks are exposed (pl. 1). A certainty level of B is assigned because the evidence for epithermal gold mineralization is limited and ambiguous. Although the U.S. Bureau of Mines detected minor amounts of gold, silver, and tungsten in silicified rocks near the southwest end of the study area (table 1 , nos. 3 and 6 ), no visible signs of mineralization have been found and a hydrothermal origin for the silicified rocks has not been proven. Further geochemical studies of all the areas of silicified rocks would help increase the certainty of the present interpretation. See Appendix 1 and Figure 3 for definitions of levels of mineral resource potential and certainty.

We have not identified any potential for placer gold resources in the study area, but some discussion is warranted because of the history of placer gold mining in areas immediately south of the study area. The stratigraphically higher parts of the Paleocene and Eocene Goler Formation that are exposed within and adjacent to the study area do not appear to contain any fossil placer gold deposits. These strata are finer grained than those of the auriferous basal conglomerate unit of the Goler Formation at Goler Gulch and they were deposited by west-flowing streams, whereas the basal conglomerate unit was deposited by south-flowing streams (Cox, 1982). The placer gold south of the study area along Bonanza
Gulch consists of flakes and small nuggets concentrated at the base of Quaternary terrace gravel (Troxel and Morton, 1962). This gold most likely was recycled from the coarse-grained basal conglomerate unit (herein called the conglomerate unit of Bonanza Gulch) of the Miocene Ricardo Formation, which crops out prominently at the head of Bonanza Gulch (see also Hulin, 1934, p. 424-425). However, gold concentrations in this unit have not been located by historical mining and prospecting activities and we infer that the gold is widely disseminated at low concentrations throughout the conglomerate unit. The conglomerate unit consists of an upward-fining, horizontally-stratified sequence of boulder, cobble, and pebble conglomerate and pebbly sandstone that is 600 to $800 \mathrm{ft}$ thick near the head of Bonanza Gulch. It overlies a fairly smooth, unchanneled erosion surface cut across the Goler Formation. These characteristics suggest that the conglomerate was deposited very rapidly in shallow ephemeral channels of a large alluvial fan. Under such conditions there probably was little opportunity for streams to concentrate gold. Thus, although Quaternary gold placers south of the study area probably are derived from the conglomerate unit of Bonanza Gulch, we conclude that the gold is probably widely disseminated throughout the unit in low concentrations and that there is no apparent potential for fossil placer gold deposits in it.

Quaternary gravel deposits within the study area also lack characteristics favorable for placer gold occurrences because the gravel generally was deposited in geomorphic settings, such as alluvial fans, that do not favor prolonged reworking of stream sediment necessary to concentrate the gold. Moreover, most of the gravel was derived from unfavorable source rocks, including volcanic strata of the Ricardo Formation and the Black Mountain Basalt.

Alluvium and volcanic rocks in the study area are potential sources of various industrial materials but they have attracted little commercial interest, probably because of their distance from major markets and their relative inaccessibility in comparison to neighboring sources in Indian Wells and Fremont Valleys (fig. 1). The middle and upper parts of the tuffaceous rocks unit of the Ricardo Formation consist mainly of orange-pink and grayish-orange lapilli tuff. Because abundant rock fragments other than pumice are present, these parts of the tuff would require more processing than the white pumice tuff at the base of the tuffaceous rocks unit. Such contamination may explain the lack of past commercial interest in these rocks. A thick layer of andesite flow-breccia containing lenses of perlite crops out near the center of the tuffaceous rocks unit 2 to $4 \mathrm{mi}$ southwest of the study area (Dibblee and Gay, 1952, p. 50). This layer crops out discontinuously in the study area but it is much thinner there and lacks perlite.

Rubble from flows of the Black Mountain Basalt that has been affected by landslides throughout much of the Black Hills could be used for riprap. Such material has been quarried locally outside the study area at the northwest end of the Black Hills. Other common rock materials, particularly sand and gravel, are present in the study area and could be used for various industrial purposes. Development of these materials is unlikely in the foreseeable future, 
however, because similar materials of equal or better quality are abundant closer to local markets and because the probable cost of mining exceeds the present market value of some of the

\section{materials.}

Geologic data suggest a low probability for large concentrations of coal or hydrocarbons in the Cenozoic rocks of the study area. Evidence for a hydrocarbon potential is negligible; the volcanic rocks and fluviatile sedimentary strata underlying most of the study area might include suitable reservoir rocks but lack hydrocarbon source beds. Marine siltstone present near the top of the Goler Formation at the north end of the study area is generally strongly oxidized and only rarely contains carbonaceous lenses. Moreover, organic material observed microscopically in this siltstone consists largely of pollen and other terrestrial detritus that would have been unsuitable for generation of petroleum. Paleozoic marine strata of the Garlock assemblage probably extend beneath the study area in the subsurface, but any hydrocarbons originally present in these rocks were destroyed or expelled by greenschist-facies metamorphism during Mesozoic time.

\section{REFERENCES CITED}

Atabek'yants, K.P., 1973, Zonation in primary halos of Yuzhnoye auriferous ores as influenced by formation characteristics of the deposit: International Geological Review, v. 15, no. 12, p. 1394-1401.

Baker, C.L., 1912, Physiography and structure of the western El Paso Range and the southern Sierra Nevada: University of California Publications, Bulletin of the Department of Geology, v. 7, p. 117-142.

Bonham, H.F., Jr., and Giles, D.L., 1983, Epithermal gold/silver deposits: The geothermal connection, in Geothermal Resources Council, The role of heat in the development of energy and mineral resources in the northern Basin and Range province: Geothermal Resource Council Special Report no. 13. p. 257-262.

Bushnell, M.M., and Morton, P.K., 1982, National Uranium Resource Evaluation, Trona quadrangle, California: U.S. Department of Energy, Report PGJ/F-038(82), 50 p.

Carr, M.D., Poole, F.G., and Christiansen, R.L., 1984, Pre-Cenozoic geology of the El Paso Mountains, southwestern Great Basin, California--A summary in Lintz, Joseph, Jr., ed," Western geological excursions, 1984 annual meetings of the Geological Society of America and affiliated societies at Reno, v. 4: Reno, Nev., MacKay School of Mines, p. 84-93.

Chesterman, C.W., 1956, Pumice, pumicite, and volcanic cinders in California: California Division of Mines Bulletin 174, 119 p.

Cox, B.F., 1982, Stratigraphy, sedimentology, and structure of the Goler Formation (Paleocene), El Paso Mountains, California: Implications for Paleogene tectonism on the Garlock fault zone: Riverside, University of California, Ph.D. thesis, 248 p.
Cox, B.F., and Edwards, L.E., 1984, Possible marginalmarine deposits in the Goler Formation (Paleocene), El Paso Mountains, California: EOS, Transactions, American Geophysical Union, v. 65, p. 1084.

Detra, D.E., Erickson, M.S., Tucker, R.E., Diggles, M.F., and Parduhn, N.L., 1984, Analytical results and sample locality map of stream-sediment and heavy mineral concentrate samples from the El Paso Mountains Wilderness Study Area (CDCA164), Inyo County, California: U.S. Geological Survey Open-File Report 84-571, 11 p.

Dibblee, T.W., Jr., 1952, Geology of the Saltdale quadrangle, California: California Division of Mines Bulletin 160, p. 7-43.

----1954, Geologic map of the Inyokern quadrangle: U.S. Geological Survey Open-File Report 59-31, scale $1: 62,500$.

-.--1967, Aerial geology of the western Mojave Desert, California: U.S. Geological Survey Professional Paper 522, 153 p.

Dibblee, T.W., Jr., and Gay, T.E., Jr., 1952, Mineral deposits of Saltdale quadrangle: California Division of Mines Bulletin 160, p. 45-64.

Gaps, R.S., 1984, Mineral resources of the El Paso Mountains Wilderness Study Area (BLM No. CDCA-164), Kern County, California: U.S. Bureau of Mines Mineral Lands Assessment MLA 40-84. $18 \mathrm{p}$.

Geodata International, 1978, Aerial radiometric and magnetic survey, Trona national topographic map, California: U.S. Department of Energy, Report GJBX-65 (79), Grand Junction, Colo., $56 \mathrm{p}$., scale $1: 500,000$.

Grimes, D.J., and Marranzino, A.P., 1968, Directcurrent arc and alternating-current spark emission spectrographic field methods for the semiquantitative analysis of geologic materials: U.S. Geological Survey Circular 591,6 p.

Hulin, C.D., 1934, Geologic features of the dry placers of the northern Mojave Desert: California Journal of Mines and Geology, v. 30, no. 4, p. 417-426.

Jennings, C.W., Burnett, J.L., and Troxel, B.W., compilers, 1962, Trona sheet, Geologic map of California: California Division of Mines and Geology, Geologic Atlas of California, scale $1: 250,000$.

Meisinger, A.C., 1984, Pumice and Pumicite, in U.S. Bureau of Mines, Mineral commodity summaries 1984: Washington, D.C., U.S. Bureau of Mines, p. 121-122.

Smith, G.I., 1962, Large lateral displacement on Garlock fault, California, as measured from offset dike swarm: American Association of Petroleum Geologists Bulletin, v. 46, no. 1, p. 85104.

Smith, G.I., and Ketner, K.B., 1970, Lateral displacement on the Garlock fault, southeastern California, suggested by offset sections of similar metasedimentary rocks: U.S. Geological Survey Professional Paper 700-D, p. D1-D9.

Troxel, B.W., and Morton, P.K., 1962, Mines and mineral resources of Kern County, California: California Division of Mines and Geology, County Report 1, 370 p. 
Vredenburgh, L.M., Shumway, G.L., and Hartil, R.D., 1981, Desert fever-an overview of mining in the California Desert: Canoga Park, Calif., Living West Press, 323 p.

Weissberg, B.G., 1969, Gold-silver ore-grade precipi- tates from New Zealand thermal waters: Economic Geology, v. 64, p. 95-108.

Zbur, R.T., 1963, A geophysical investigation of Indian Wells Valley, California: China Lake, Calif., U.S. Naval Ordnance Test Station, 96 p. 
APPENDIX 1. Definition of levels of mineral resource potential and certainty of assessment

Mineral resource potential is defined as the likelihood of the presence of the mineral resources in a defined area; it is not a measure of the amount of resources or their profitability.

Mineral resources are concentrations of naturally occurring solid, liquid, or gaseous materials in such form and amount that economic extraction of a commodity from the concentration is currently or potentially feasible.

Low mineral resource potential is assigned to areus where geologic, geochemical, and geophysical characteristics indicate a geologic environment where the existence of resources is unlikely. This level of potential embraces areas of dispersed mineralized rock as well as areas having few or no indications of mineralization. Assignment of low potential requires specific positive knowledge; it is not to be used as a catchall for areas where adequate data are lacking.

Moderate mineral resource potential is assigned to areas where geologic, geochemical, and geophysical characteristics indicate a geologic environment favorable for resource occurrence, where interpretations of data indicate a reasonable chance for resource accumulation, and where an application of genetic and (or) occurrence models indicates favorable ground.

High mineral resource potential is assigned to areas where geologic, geochemical, and geophysical characteristics indicate a geologic environment favorable for resources, where interpretations of data indicate $a$ high likelihood for resource accumulation, where data support occurrence and (or) genetic models indicating presence of resources, and where evidence indicates that mineral concentration has taken place. Assignment of high resource potential requires positive knowledge that resource-forming processes have been active in at least part of the area; it does not require that occurrences or deposits be identified.

Unknown mineral resource potential is assigned to areas where the level of knowledge is so inadequate that classification of the area as high, moderate, or low would be misleading. The phrase "no mineral resource potential" applies only to a specific resource type in a well defined area. This phrase should not be used if there is the slightest possibility of resource occurrence; it is not appropriate as the summary rating for any area.

Expressions of the certainty of the mineral resource assessment incorporate a consideration of (1) the adequacy of the geologic, geochemical, geophysical, and resource data base available at the time of the assessment, (2) the adequacy of the occurrence or genetic model used as the basis for a specific evaluation, and (3) an evaluation of the likelihood that the expected mineral endowment of the area is, or could be, economically extractable.

Levels of certainty of assessments are denoted by letters, A-D (fig. 3).

A. The available data are not adequate to determine the level of mineral resource potential. Level A is used with an assignment of unknown mineral resource potential.

B. The available data are adequate to suggest the geologic environment and the level of mineral resource potential, but either evidence is insufficient to establish precisely the likelihood of resource occurrence, or occurrence and (or) genetic models are not known well enough for predictive resource assessment.

C. The available data give a good indication of the geologic environment and the level of mineral resource potential, but additional evidence is needed to establish precisely the likelihood of resource occurrence, the activity of resource-forming processes, or available occurrence and (or) genetic models are minimal for predictive applications.

D. The available data clearly define the geologic environment and the level of mineral resource potential, and indicate the activity of resourceforming processes. Key evidence to interpret the presence or absence of specified types of resources is available, and occurrence and (or) genetic models are adequate for predictive resource assessment.

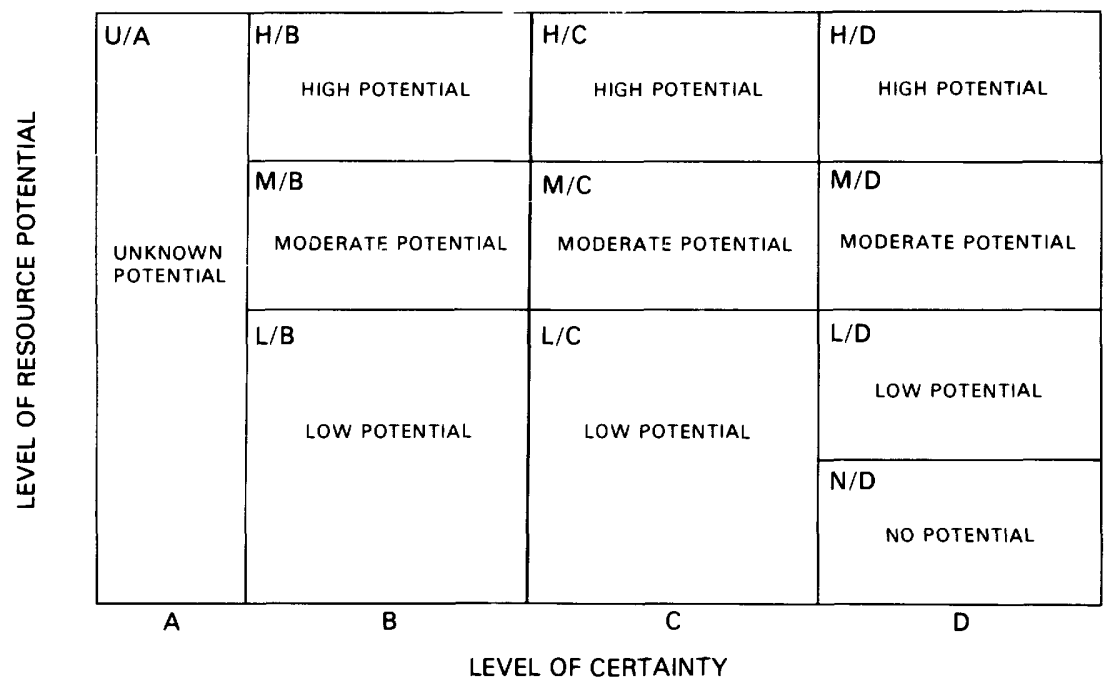

Figure 3.--Major elements of mineral resource potential/certainty classification 


\begin{tabular}{|c|c|c|c|c|}
\hline $\begin{array}{l}\text { Map } \\
\text { No. }\end{array}$ & Name & Geology & $\begin{array}{l}\text { Workings and } \\
\text { production }\end{array}$ & Sample and resource data \\
\hline & *Calsileo mine & $\begin{array}{l}\text { The mine is in a tuff-breccia unit within } \\
\text { the Ricardo Formation. The tuff-breccia } \\
\text { is composed of lapilli tuff, andesite, and } \\
\text { rhyolite rock fragments, quartz and } \\
\text { feldspar crystals, and fine white volcanic } \\
\text { ash. At the mine, the tuff-breccia is } 20 \\
\text { to } 30 \mathrm{ft} \text { thick and dips } 15^{\circ} \text { to } 30^{\circ} \mathrm{NW} \text {. } \\
\text { Portions of the tuff-breccia show } \\
\text { evidence of some silicification. This unit } \\
\text { pinches out } 1 \text { mi northeast of the mine. }\end{array}$ & $\begin{array}{l}\text { Open pit } 1,600 \mathrm{ft} \text { long, } 30 \text { to } 50 \mathrm{ft} \\
\text { wide, } 15 \text { to } 25 \mathrm{ft} \text { deep. Over } \\
25,000 \text { tons of pumice produced by } \\
1958 \text { (Troxel and Morton, } 1962 \text { ). } \\
\text { Approximately } 1,500 \text { tons of } \\
\text { pumice produced per year be- } \\
\text { tween } 1959 \text { and } 1968 \text {, the last } \\
\text { year of production. }\end{array}$ & $\begin{array}{l}\text { Additional pumice resources remain at } \\
\text { the mine. }\end{array}$ \\
\hline 1 & $\begin{array}{l}\text { *Name unknown } \\
\text { prospect }\end{array}$ & Vesicular to amygdaloidal basalt. & One small pit. & $\begin{array}{l}\text { This pit was probably dug by mineral } \\
\text { collectors in search of opal. One piece } \\
\text { of precious opal was reportedly found in } \\
\text { the drainage nearby (Dr. Carl Austin, } \\
\text { personal commun., 1983). The amygdal- } \\
\text { oidal basalt is similar in appearance to } \\
\text { opal-bearing basalt which crops out } \\
\text { several miles southwest of the study } \\
\text { area. }\end{array}$ \\
\hline 2 & $\begin{array}{l}\text { Name unknown } \\
\text { prospect }\end{array}$ & $\begin{array}{l}\text { A tuff-breccia within the Ricardo } \\
\text { Formation. The tuff-breccia is com- } \\
\text { posed of lapilli pumice fragments and } \\
\text { some quartz and feldspar crystals in a } \\
\text { matrix of white volcanic ash. This } \\
\text { material is similar in appearance to the } \\
\text { tuff mined at the Calsilco mine. The } \\
\text { tuff-breccia is not well enough exposed } \\
\text { to determine attitude or thickness. }\end{array}$ & One bulldozer cut. & $\begin{array}{l}\text { No reserves indicated. The pumice is a } \\
\text { subeconomic resource for all but local } \\
\text { uses. No current market exists locally. }\end{array}$ \\
\hline 3 & $\begin{array}{l}\text { *Name unknown } \\
\text { prospect }\end{array}$ & $\begin{array}{l}\text { This prospect is in tuff and siliceous } \\
\text { layers within the Ricardo Formation. } \\
\text { The tuff is composed of glassy, scoria- } \\
\text { ceous pumice fragments in a matrix of } \\
\text { smaller glass fragments. The siliceous } \\
\text { layers are opaline chert according to } \\
\text { Dibblee (1952). The opaline chert is tan, } \\
\text { gray, or white with sparce dark patches, } \\
\text { and varies in appearance from white, } \\
\text { vitreous opal to translucent or trans- } \\
\text { parent chalcedony. Banding is not } \\
\text { common. This opaline chert strikes } \\
\text { northeast, dips about 20 NW., and is } \\
\text { similar to the opal cap asociated with } \\
\text { precious metal mineralization in the } \\
\text { Lava Mountain (Gaps, 1984), about } 20 \text { mi } \\
\text { to the east. }\end{array}$ & Several bulldozer trenches. & $\begin{array}{l}\text { One sample of opaline chert contained } \\
0.0024 \mathrm{oz} / \text { ton gold, } 0.038 \mathrm{oz} / \text { ton silver, } \\
\text { and } 0.0018 \text { percent tungsten trioxide } \\
\left(\mathrm{WO}_{3}\right) \text {. }\end{array}$ \\
\hline 4 & $\begin{array}{l}\text { *Name unknown } \\
\text { prospect }\end{array}$ & $\begin{array}{l}\text { The workings are in a white chert or } \\
\text { chalcedony bed in the Ricardo Forma- } \\
\text { tion. The bed strikes between N. } 20^{\circ} \text { and } \\
60^{\circ} \text { E. and dips } 5^{\circ} \text { to } 15^{\circ} \mathrm{NW} \text {. This bed } \\
\text { could be equivalent to the opaline chert } \\
\text { at prospect No. } 3 \text {. }\end{array}$ & One adit, $140 \mathrm{ft}$ long. & $\begin{array}{l}\text { Five chip samples were taken in the } \\
\text { adit. Two of the samples contained } \\
0.0002 \text { and } 0.0004 \mathrm{oz} / \text { ton gold. }\end{array}$ \\
\hline 5 & $\begin{array}{l}\text { *Name unknown } \\
\text { prospect }\end{array}$ & $\begin{array}{l}\text { Exposed by the workings is a tuff-breccia } \\
\text { similar to that which was mined at the } \\
\text { Calsilco mine. The tuff breccia is } \\
\text { composed of pumice lapilli, some quartz } \\
\text { and feldspar crystals and rock fragments } \\
\text { in a matrix of volcanic ash. The tuff was } \\
\text { not well enough exposed to determine } \\
\text { thickness or attitude. }\end{array}$ & $\begin{array}{l}\text { Open cuts about } 15 \mathrm{ft} \text { deep and } 25 \\
\mathrm{ft} \text { wide. Concrete bins were also } \\
\text { constructed. }\end{array}$ & $\begin{array}{l}\text { One sample taken is similar in composi- } \\
\text { tion to raw material from the Calsilco } \\
\text { mine. Pumice is subeconomic for all but } \\
\text { local use. }\end{array}$ \\
\hline 6 & $\begin{array}{l}\text { Name unknown } \\
\text { prospect }\end{array}$ & $\begin{array}{l}\text { A bed of white chert or chalcedony in } \\
\text { the Ricardo Formation. The bed strikes } \\
\text { about } \mathrm{N} .15^{\circ} \mathrm{E} \text {., dips about } 10^{\circ} \mathrm{NW} \text {., and } \\
\text { is similar in appearance to the chert at } \\
\text { prospect No. } 4 \text {. }\end{array}$ & One bulldozer trench or pit. & $\begin{array}{l}\text { One sample taken contained only back- } \\
\text { ground amounts of metals. }\end{array}$ \\
\hline 7 & $\begin{array}{l}\text { Name unknown } \\
\text { prospect }\end{array}$ & $\begin{array}{l}\text { The working penetrates a vesicular } \\
\text { basalt of the Black Mountain Basalt, and } \\
\text { tuffaceous sedimentary strata, probably } \\
\text { of the Ricardo Formation. }\end{array}$ & One shaft, $40 \mathrm{ft}$ deep. & $\begin{array}{l}\text { One grab sample from the dump con- } \\
\text { tained only background amounts of } \\
\text { metals. }\end{array}$ \\
\hline 8 & *Dennis claims & $\begin{array}{l}\text { The workings are in thinly bedded shale } \\
\text { and chert. These beds are part of a pre- } \\
\text { Tertiary formation that does not crop } \\
\text { out within the wilderness study area. } \\
\text { Secondary copper minerals occur on } \\
\text { fracture surfaces and in association with } \\
\text { thin quartz lenses. }\end{array}$ & $\begin{array}{l}\text { Two short adits, one about } 10 \mathrm{ft} \\
\text { long and one flooded, and one pit. }\end{array}$ & $\begin{array}{l}\text { Three chip samples were taken. They } \\
\text { contained } 0.068,0.0010 \text {, and } 0.0094 \\
\text { oz/ton gold; } 0.152,0.022 \text {, and } 0.383 \\
\text { oz/ton silver; and } 0.44 \text { percent, } 0.0005 \\
\text { percent and } 0.01 \text { percent copper, respec- } \\
\text { tively. }\end{array}$ \\
\hline
\end{tabular}


